Images $\ln .$.

\title{
Proliferation of a chronic thyroid adenoma
}

\author{
Paul Grant, ${ }^{1}$ Nick Vaughan, ${ }^{1}$ Charles Zammit² \\ ${ }^{1}$ Department of Diabetes, Royal Sussex County Hospital, Brighton, UK \\ ${ }^{2}$ Department of Surgery, Royal Sussex County Hospital, Brighton, UK \\ Correspondence to Paul Grant, drpaul.grant@doctors.org.uk
}

\section{DESCRIPTION}

An 83-year-old Jehovah's witness presented with a 4-month history of dysphagia and neck discomfort. She was known to have a thyroid adenoma, originally diagnosed back in the 1960s, but declined operative treatment at the time due to religious issues surrounding the need for a blood transfusion.

She was presently concerned about a progressive enlargement of the right side of her neck over the course of 6 months. Physical examination revealed a massive goitre. The upper and lower margins were not readily definable. Serum thyroid stimulating hormone and free thyroxine levels were normal. An urgent CT scan of her head and neck was ordered (figure 1). This demonstrated a significantly large thyroid mass with a necrotic centre and retrosternal extension. Her oesphagus was compromised and confirmed on oesophagogastroduodenoscopy. Chest x-ray confirmed tracheal deviation (figure 2).
Total thyroidectomy and neck dissection was performed and histology revealed fine, granular, calcified tissue, consistent with a thyroid adenoma. The patient's symptoms resolved following surgery.

The images are important because they demonstrate the significant size that thyroid masses can reach before they cause significant airway or oesophageal compromise especially if they are slow growing over many years.

Assessment of thyroid masses is threefold: clinically with regards to symptoms, on examination in terms of palpation and technically in terms of imaging and functional performance-that is, spirometry and endoscopy.

\section{Competing interests None.}

Patient consent Not obtained.

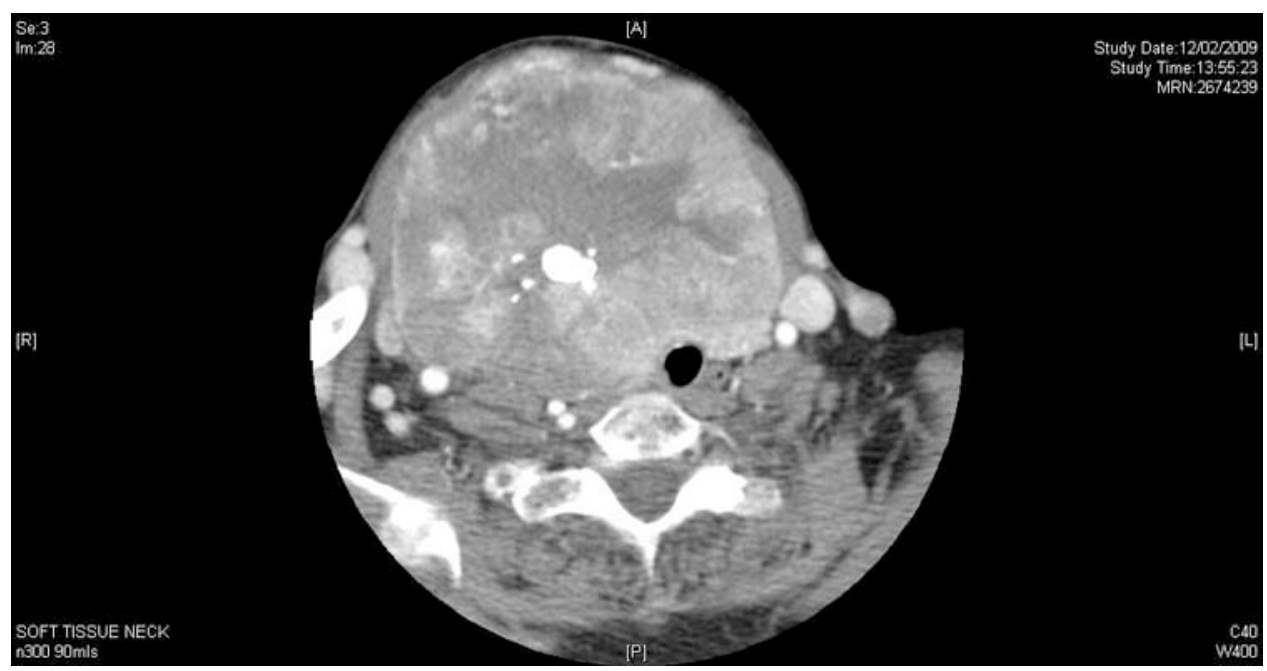

Figure 1 CT of neck showing tracheal compromise. 


\section{BMJ Case Reports}

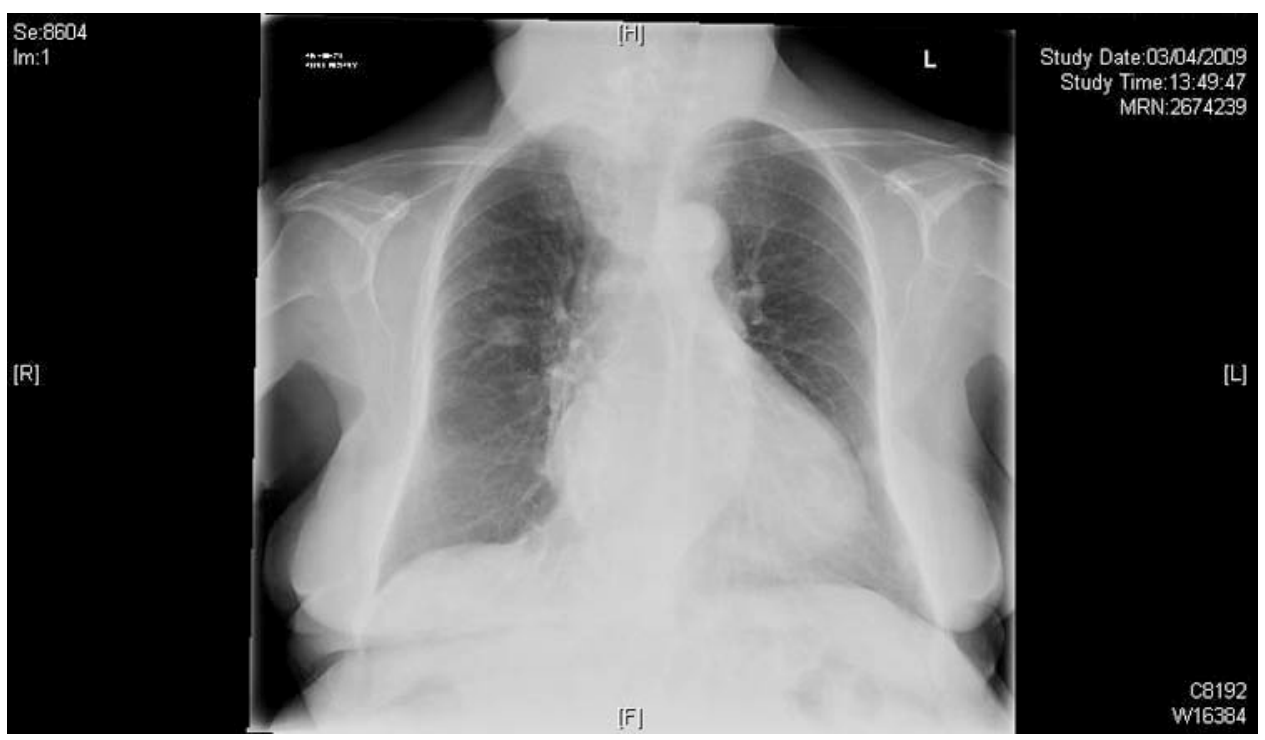

要

Figure 2 Chest $x$-ray showing tracheal deviation.

This pdf has been created automatically from the final edited text and images.

Copyright 2010 BMJ Publishing Group. All rights reserved. For permission to reuse any of this content visit http://group.bmj.com/group/rights-licensing/permissions.

BMJ Case Report Fellows may re-use this article for personal use and teaching without any further permission.

Please cite this article as follows (you will need to access the article online to obtain the date of publication).

Grant P, Vaughan N, Zammit C. Proliferation of a chronic thyroid adenoma. BMJ Case Reports 2010;10.1136/bcr.07.2010.3202, date of publication

Become a Fellow of BMJ Case Reports today and you can:

- Submit as many cases as you like

- Enjoy fast sympathetic peer review and rapid publication of accepted articles

- Access all the published articles

- Re-use any of the published material for personal use and teaching without further permission

For information on Institutional Fellowships contact consortiasales@bmjgroup.com

Visit casereports.bmj.com for more articles like this and to become a Fellow 